\title{
The effects of benzyladenine and gibberellic acid on adventitious root formation in apple stem discs
}

\author{
N Pawlicki, M Welander * \\ The Swedish University of Agricultural Sciences, Department of Horticulture, Box 55, S-23053 Alnarp, Sweden
}

(COST Meeting, 21-23 May 1992, Dijon, France)

\begin{abstract}
Summary - The effects of $\mathrm{BA}$ (benzyladenine) and $\mathrm{GA}_{3}$ (gibberellic acid) were studied in stem discs of the apple rootstock M9 cv Jork. The disks were first cultured for $24 \mathrm{~h}$ in darkness on rooting medium containing $24.6 \mu \mathrm{M}$ IBA, and then transferred to light onto a hormone-free medium or exposed to a medium supplemented with either BA $(1.3 \mu \mathrm{M})$ or $\mathrm{GA}_{3}(10 \mu \mathrm{M})$ for different periods during the rooting procedure. The $\mathrm{BA}$ treatment strongly inhibited root formation especially when applied at the beginning of the rooting period. $\mathrm{GA}_{3}$ also reduced rooting when applied both at the beginning and at the end of the rooting period.
\end{abstract}

apple rootstock / adventitious root formation / auxin / benzyladenine / gibberelic acid

Résumé - Effets de la benzyladénine et de l'acide gibbérellique sur l'enracinement de disques de tiges de pommier. Les effets de la benzyladénine $(B A)$ et de l'acide gibbérellique $\left(G A_{3}\right)$ sur l'enracinement sont étudiés sur des disques de tige du pommier porte-greffe M9 cv Jork. Les disques, d'abord cultivés pendant $24 \mathrm{~h}$ à l'obscurité sur un milieu d'enracinement supplémenté de $24,6 \mu \mathrm{mol} . \mathrm{t}^{-1}$ d'AlB, sont ensuite transférés à la lumière sur le milieu de base dépourvu d'hormones, ou exposés au milieu de base supplémenté en BAP $\left(1,3 \mu \mathrm{mol}^{-1} \mathrm{~F}^{-1}\right)$ ou en $\mathrm{GA}_{3}\left(10 \mu \mathrm{mol}^{-r^{-1}}\right)$ pendant différentes périodes. Un transfert des disques sur le milieu supplémenté en $B A$ inhibe fortement la formation des racines, spécialement lorsque le traitement a lieu en début de culture. GA3 inhibe également généralement la formation des racines, à la fois lorsqu'il est appliqué en début et en fin de culture.

pommier porte-greffe / racine adventive / auxine / benzyladénine / acide gibbérellique

\section{INTRODUCTION}

The propagation of woody plant species by cuttings or tissue culture is often limited by poor rooting. Moreover, in woody plants rooting ability declines with maturation at the time when interesting traits can be identified. This limits the commercial production of desirable genotypes (Davis et al, 1988). Although several physiological and biochemical factors have been identified as essential in the process of rooting, their effect on the initiation of root primordia still needs to be clarified. In cuttings, it is known that applied auxins (indole-3-butyric acid or naphthalene acetic acid) increase, whereas applied cytokinins (van Staden and Harty, 1988) and gibberellins (Hansen, 1988) inhibit adventitious root formation. Van der Kriek- en et al (1991), studying the root formation in woody crops, have developed a model system with 1-mm stem discs of the apple rootstock M9 cv Jork. Using the stem discs system, it was shown that a 24-hour auxin pulse (24.6 $\mu \mathrm{M}$ IBA) in darkness resulted in the formation of adventitious roots in $>90 \%$ of the discs (Welander and Pawlicki, 1992). In this sytem, the rooting process has been mapped by microscopic investigations (Welander and Pawlicki, 1992). This study revealed increased cambial activity after $2 \mathrm{~d}$, root primordium initials after $4 \mathrm{~d}$, and more or less differentiated root primordia after $6 \mathrm{~d}$.

Using this stem discs system, the effects of BA and $\mathrm{GA}_{3}$ on auxin-induced root initiation and subsequent development of the primordia into roots were studied. 


\section{MATERIALS AND METHODS}

\section{Shoot multiplication}

In vitro shoots of apple rootstock $\mathrm{M} 9 \mathrm{cv}$ Jork (supplied by $B$ Kunneman, Centre for Plant Tissue Culture Research, Lisse, The Netherlands) were subcultured every 4 or 5 wk on medium consisting of MS salts (Murashige and Skoog, 1962) to which $4.4 \mu \mathrm{M}$ BA, 0.5 $\mu \mathrm{M}$ IBA, $30 \mathrm{~g} / \mathrm{l}$ sorbitol, and $7 \mathrm{~g} / \mathrm{l}$ agar (Difco Bacto) had been added. The medium was adjusted to $\mathrm{pH} 5.5$ before autoclaving. The cultures were incubated in growth chambers at $24 \pm 1{ }^{\circ} \mathrm{C}$ with a 16 -h photoperiod at an irradiance of $33 \mu \mathrm{mol} \mathrm{m} \mathrm{m}^{-2} \mathrm{~s}^{-1}$ provided by cool white fluorescent tubes.

\section{Rooting experiments}

For the rooting experiments, the $10 \mathrm{~mm}$ basal part of stems (excluding the callus at the stem basis) from 4 or 5-wk-old axillary shoots were cut into 1-mm thick discs with a razor blade. The stem discs were cultured, basal part upwards, for 24-h darkness on a basal rooting medium (BM) supplemented with $24.6 \mu \mathrm{M}$ $\mathrm{IBA}$, and then transferred to $\mathrm{BM}$ and light conditions. $\mathrm{BM}$ consisted of macronutrients in half strength and micronutrients according to Lepoivre (Quoirin et al, 1977), COST vitamins (thiamine- $\mathrm{HCl} 1.0 \mathrm{mg} / \mathrm{l}$, myoinositol $100 \mathrm{mg} / \mathrm{l}$, nicotinic acid $0.5 \mathrm{mg} / \mathrm{l}$ and pyridoxine- $\mathrm{HCl} 0.5 \mathrm{mg} / \mathrm{l}), 100 \mathrm{mg} / \mathrm{l}$ proline, $30 \mathrm{~g} / \mathrm{l}$ sucrose, $7.0 \mathrm{~g} / \mathrm{l}$ agar (Difco Bacto) at $\mathrm{pH} 5.5$. Temperature and light conditions were as described for shoot multiplication.

\section{$B A$ and $G A_{3}$ treatments}

To examine the effects of $B A$ and $G_{3}$ on rooting, stem discs were incubated after the 24-h dark period on IBA on BM supplemented with $1.3 \mu \mathrm{M}$ BA or $10 \mu \mathrm{M}$ $\mathrm{GA}_{3}$ for different time periods according to the procedure described in figure 1.

Rooting, expressed as the percentage of discs producing at least 1 root and the average number of roots per rooted disc were recorded in every experiment after $20 \mathrm{~d}$ of culture. Thirty discs were used per treatment in each of 3 replications.

\section{RESULTS}

\section{Effect of BA treatment}

Figure 2 shows rooted stem discs after $20 \mathrm{~d}$ of culture. The explants were cultured for $24 \mathrm{~h}$ in darkness on BM supplemented with $24.6 \mu \mathrm{M}$ IBA and then transferred to light on a hormone-free medium. As described in a previous paper (Welander and Pawlicki, 1992), 94\% of cultured discs produced roots. An exposure time of the discs to $B A>1 d$ strongly inhibited the formation of adventitious roots, especially when the treatment took place at the beginning of the rooting period (fig $3 \mathrm{~A}$ ). After only $1 \mathrm{~d}$ on the rooting medium, $39.5 \%$ and $15.1 \%$ were obtained for short exposure times to BA ( 2 and $3 \mathrm{~d}$, respectively). Nevertheless, these percentages were significantly

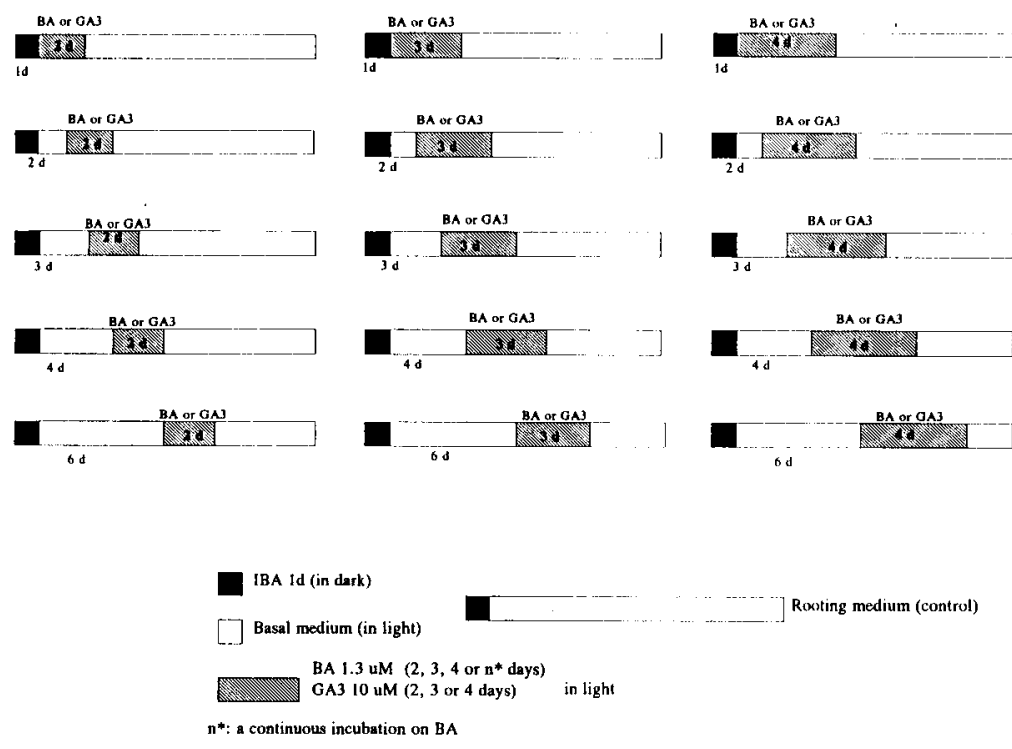

Fig 1. Procedure for $B A$ and $G A 3$ treatments with apple rootstock $M 9 \mathrm{cv}$ Jork stem discs. 


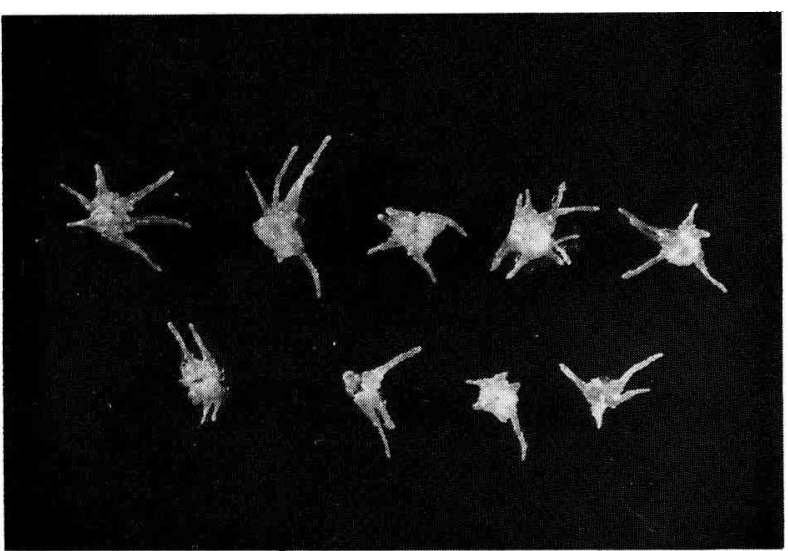

Fig 2. In vitro rooting of stem discs from the apple rootstock M9 cv Jork.

lower than the control. After $2 d$ on the rooting medium, exposure of the discs to BA medium for 2 or $3 \mathrm{~d}$ exerted a pronounced inhibition of rooting. Less than $10 \%$ of rooting was noted, and callus formation was then observed on the stem discs. When a BA treatment of $\geq 4 \mathrm{~d}$ ( $n$ days) was applied, after 1 or $2 \mathrm{~d}$ on the rooting medium no rooting or a very low percentage of rooting (2\%) was observed. After extended culture periods ( $\geq 6 \mathrm{~d}$ on the rooting medium) before transfer to $B A$ medium, the rooting percentage was not affected by the length of BA treatment. At this time the root primordia had been formed (Welander and Pawlicki, 1992), indicating that BA does not inhibit root outgrowth. Nevertheless, the observed percentages remained low $(\approx 53 \%)$ and significantly different from the control $(94 \%)$. BA treatment also reduced the number of roots per rooted stem disc (fig 3B). For the control (no BA treatment) an average value of $5.9( \pm 0.9)$ roots per rooted disc was obtained, while after the BA treatment the number of roots per rooted discs oscillated around an average value of $1.7( \pm 0.6)$.

\section{Effect of $G A_{3}$}

When $\mathrm{GA}_{3}$ was applied for periods of 2, 3 or $4 \mathrm{~d}$ (fig $4 \mathrm{~A}$ ) after $1 \mathrm{~d}$ on the rooting medium, the formation of roots on the discs was inhibited (22$44 \%$ according to the time of $\mathrm{GA}_{3}$ exposure) in comparison with the control (94\%). Likewise, a $\mathrm{GA}_{3}$ treatment applied after $6 \mathrm{~d}$ on the rooting medium exerted an inhibition of root formation, especially for exposure times of $3 d(36.7 \%)$ and
$4 \mathrm{~d}(47.7 \%)$. However, when the $\mathrm{GA}_{3}$ treatment was given after 3 or $4 \mathrm{~d}$ on the rooting medium, the rooting percentages were not significantly different from the control, regardless of the time of exposure. One $d$ of $\mathrm{GA}_{3}$ exposure did not result in the same inhibition, irrespective of the time at which the treatment was given, while continuous exposure always inhibited rooting (data not shown). The number of roots per rooted stem discs is given in figure 4B. For the different treatments, the number of roots which were formed was reduced (an average value of $2.5 \pm 0.9$ roots per rooted discs) in comparison with the control, but was not completely inhibited (fig 5).

\section{DISCUSSION AND CONCLUSION}

Exogenously supplied auxin is essential for root initiation on stem discs, but the rooting response can be modified by other plant hormones such as benzyladenine or gibberellic acid.

Benzyladenine inhibits adventitious root formation on stem discs, and does this more strongly when applied after $2 \mathrm{~d}$ on the rooting medium (fig 4), which corresponds to increased cambial activity (Welander and Pawlicki, 1992). De Klerk et al (1992) also found an inhibitory effect of BA $(1 \mu \mathrm{M})$ using the same system to study rooting in Malus. Although rooting was unaffected by the exposure time of BA applied after $6 \mathrm{~d}$ on the rooting medium, rooting percentage was still low in comparison to control. This could be due to asynchrony of rooting (Hicks, 1987). Therefore, already formed root primordia could grow out, but new root primordia were inhibited. Indeed, during anatomical studies (Welander and Pawlicki, 1992) root primordia at different stages were observed in the stem discs after $6 \mathrm{~d}$.

An inhibitory effect of $\mathrm{GA}_{3}$ on adventitious root formation was also observed (fig 4). The inhibition of rooting by $\mathrm{GA}_{3}$ took place earlier than with BA. This could be related to a partial inhibition of endogenous starch synthesis in the plastids, as described by Coleman and Greyson (1976) in tomato. After $1 \mathrm{~d}$ under the normal conditions of rooting, no anatomical changes were noted by light microscopy (Welander and Pawlicki, 1992). However, transmission electron microscopy (TEM) showed a slight augmentation in the number of plastids (Heneen, personal observation). The other inhibitory effect occurred 

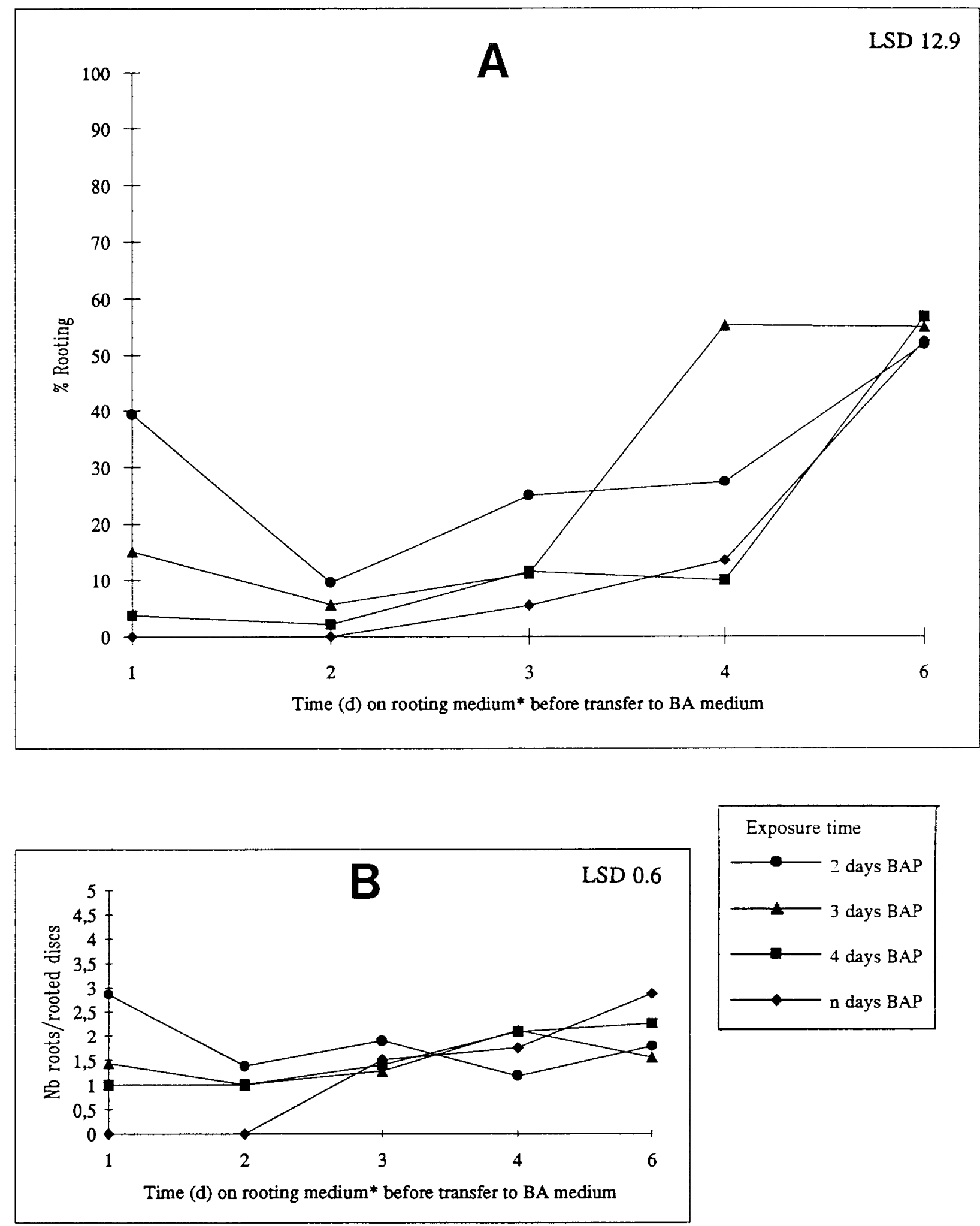

* Rooting medium: $1 \mathrm{~d}$ on $\mathrm{BM}+24.6 \mu \mathrm{M}$ IBA then $\mathrm{BM}$

Fig 3. The effect of benzyladenine $(1.3 \mu \mathrm{M})$ on the percentage of rooted discs (A) and on the number of roots per rooted disc (B) The discs were incubated on the rooting medium for $1,2,3,4$ or $6 \mathrm{~d}$ before being exposed to $1.3 \mu \mathrm{M}$ BA for various time periods. 

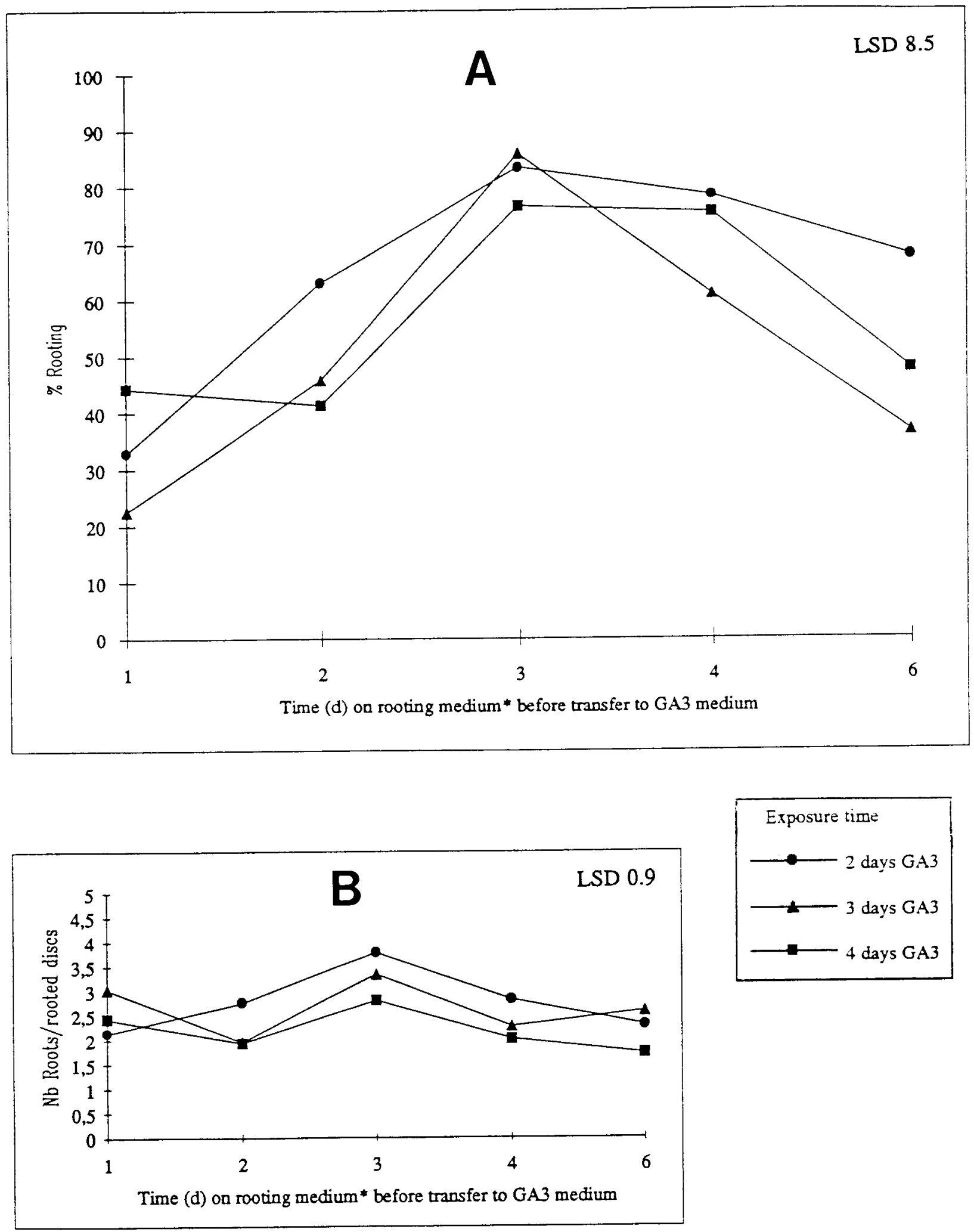

* Rooting medium: $1 \mathrm{~d}$ on $\mathrm{BM}+24.6 \mu \mathrm{M}$ then $\mathrm{BM}$

Fig 4. The effect of gibberellic acid $(10 \mu \mathrm{M})$ on the percentage of rooted discs (A) and on the number of roots per rooted disc (B)

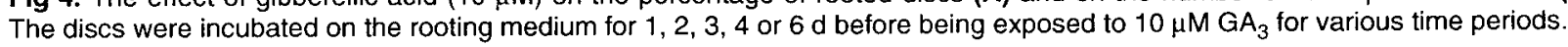




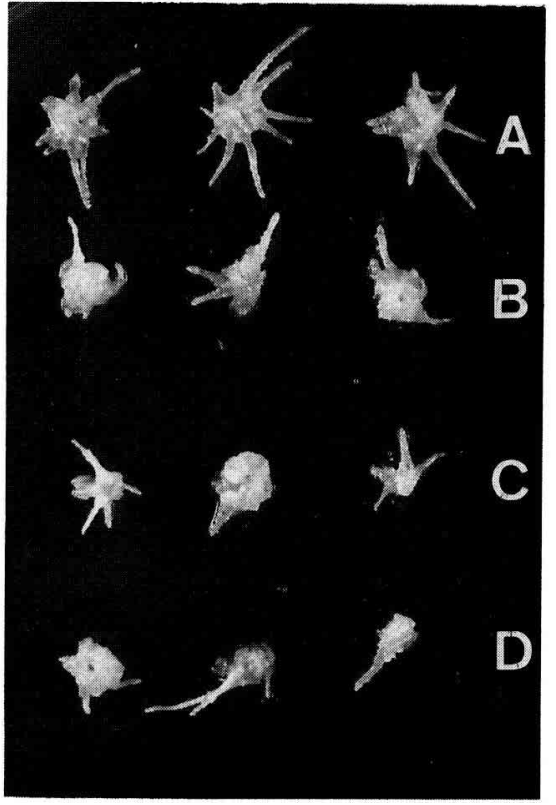

Fig 5. Adventitous root formations on $\mathrm{GA}_{3}$ treated stem discs. A: control, B: $2 d$ rooting treatment followed by $1 \mathrm{~d}$ $\mathrm{GA}_{3}$ treatment; $C: 4 d$ rooting treatment followed by $3 \mathrm{~d} \mathrm{GA}_{3}$ treatment; $\mathrm{D}: 4 \mathrm{~d}$ rooting treatment followed by $n \mathrm{~d} \mathrm{GA}_{3}$.

relatively late in the culture period. In this case, gibberellic acid probably inhibited the outgrowth of root primordia. Studying the influence of applied gibberellic acid in brittle willow (Salix fragilis L), Haissig (1972) also concluded that $\mathrm{GA}_{3}$ hindered the development of root primordia via an inhibition of mitotic activity within the initiating root primordia.

\section{ACKNOWLEDGMENTS}

The authors thank L Persson for technical assistance. This study was supported by grants from the Swedish Council for Forestry and Agriculture research.

\section{REFERENCES}

Coleman WK, Greyson RI (1979) Analysis of root formation in leaf discs of $L y c o p e r s i c o n$ esculentum Mill cultured in vitro. Ann Bot 41, 307-320

Davis TD, Haissig BE, Sankhla N (1988) Adventitious Root Formation. Advances in Plant Sciences Series (Dawis TD, Hoissig BE, Sankhla N, eds) Dioscorides Press, Portland, OR, vol 2

De Klerk GJ, Brugge J, Keppel M (1992) Successive phases during rooting of microcuttings of Malus. Acta Hortic (in press)

Haissig BE (1972) Meristematic activity during adventitious root primordium development. Plant Physiol $49,886-892$

Hansen $J(1988)$ Influence of gibberellins on adventitious root formation. In: Adventitious Root Formation. Advances in Plant Sciences Series (Davies TD, Haissig BE, Sankhla N, eds) Dioscorides Press, Portland, OR, vol 2, 162-173

Hicks GS (1987) Adventitious rooting of apple microcuttings in vitro: an anatomical study. Can J Bot 65 , 1913-1920

Murashige T, Skoog F (1962) A revised medium for rapid growth and bioassays with tobacco tissue cultures. Physiol Plant 15, 473-497

Quoirin M, Lepoivre P, Boxus P (1977) Un premier bilan de 10 années de recherches sur les cultures de méristèmes et la multiplication in vitro de fruitiers ligneux. CR Rech 1976-1977 Rapp Synthèse Stat Cultures Fruitières et Maraîchères, Centre Rech Agron de l'Étaty, Gembloux, Belgium

Van der Krieken WM, Breteler H, Visser MHM (1991) Indol butyric acid-induced root formation in apple tissue culture. Design of an experimental system, auxin metabolism and isolation of cDNA clones related to root inhibition. Acta Hortic 289, 343-344

Van Staden J, Harty AR (1988) Cytokinins and adventitious root formation. In: Adventitious Root Formation. Advances in Plant Sciences Series (Davis TD, Haissig BE, Sankhla N, eds) Dioscorides Press, Portland, OR, vol 2, 185-201

Welander M, Pawlicki N (1992) A model system for studying root regeneration in woody species. Acta Hortic (in press) 